\title{
PENGARUH PH TANAH TERHADAP PROSES BIODEGRADASI POLYCYCLIC AROMATIC HYDROCARBON (PAH) PADA TANAH TERKONTAMINASI BATUBARA
}

\author{
Gina Lova Sari ${ }^{1 *}$, Andy Mizwar ${ }^{2}$, Yulinah Trihadiningrum ${ }^{3}$ \\ ${ }^{1,2}$ Fakultas Teknik, Universitas Singaperbangsa Karawang, \\ Jl. H.S. Ronggowaluyo, Teluk Jambe Timur, Karawang, Jawa Barat 41361 \\ ${ }^{3}$ Jurusan Teknik Lingkungan, Fakultas Teknik Sipil dan Perencanaan, Institut Teknologi Sepuluh Nopember \\ Jl. Arief Rahman Hakim, Surabaya 60111 \\ *Email: ginalovasari@gmail.com
}

Diterima: 17 Nopember 2015

Direvisi: 1 Desember 2015

Disetujui: 30 Desember 2015

\begin{abstract}
ABSTRAK
Batubara alami (unburnt coal) mengandung polycyclic aromatic hydrocarbon (PAH) dengan kadar yang tinggi dan tingkat penyebaran relatif cepat. PAH sulit didegradasi karena bersifat toksik sehingga berpotensi mengkontaminasi tanah, terutama di wilayah pertambangan batubara tetapi belum mendapatkan perhatian yang serius. Kontaminasi tersebut dapat ditangani menggunakan salah satu teknologi bioremediasi yaitu cocomposting. Salah satu faktor yang mempengaruhi proses co-composting adalah $\mathrm{pH}$. Penelitian ini bertujuan untuk mengetahui pengaruh $\mathrm{pH}$ tanah terhadap biodegradasi PAH dalam proses co-composting dengan penambahan sampah organik. Co-composting dilakukan secara aerobik selama 98 hari dalam skala laboratorium. Variasi penelitian meliputi rasio tanah terkontaminasi PAH dengan sampah organik (100/), 75/25, 50/50, 25/75, dan 0/100) dan pH tanah (asam dan netral). Analisis kadar 16 EPA-PAH dilakukan menggunakan metode Gas Chromatographic Mass Spectrometric (GC-MS). Proses co-composting berlangsung dalam kondisi lingkungan yang optimal yaitu suhu mesofilik (30-31 $\left.{ }^{\circ} \mathrm{C}\right), \mathrm{pH}$ netral (6,5-7), dan kadar air optimum (50-60\%). Hasil penelitian menunjukkan bahwa biodegradasi PAH yang terjadi tidak dipengaruhi oleh kondisi $\mathrm{pH}$ tanah. Hal ini dibuktikan dengan persentase kadar PAH yang terdegradasi tidak berbeda jauh antara pH tanah awal asam dan netral di rasio T/s 25/75 yaitu 75,15\% dan 76,21\%.
\end{abstract}

Kata Kunci: Batubara, bioremediasi, co-composting, PAH, $p H$.

\begin{abstract}
Natural coal (unburnt coal) contain High level polycyclic aromatic hydrocarbons (PAH) and relatively rapid rate of spread. PAH is difficult to degrade because it is toxic, so the potential to contaminate soil, especially in the coal mining region but has not received serious attention. The contamination can be handled using one of bioremediation technologies that is co-composting. One of the factors that affect the process of co-composting is $\mathrm{pH}$. This study aims to determine the effect of $\mathrm{pH}$ soil on the biodegradation of PAHs in the process of cocomposting with the addition of organic waste. Co-composting is done aerobically for 98 days in a laboratory scale. Variations of research include the ratio of PAH contaminated soil with organic waste (100/0, 75/25, 50/50, 25/75, and 0/100) and soil $p H$ (acidic and neutral). Analysis of 16 EPA-PAH levels is done using Gas Chromatographic Mass spectrometric (GC-MS). Co-composting process takes place under optimal environmental conditions such as temperature mesophilic (30-31 $\left.{ }^{\circ} \mathrm{C}\right)$, neutral $\mathrm{pH}(6.5-7)$, and the optimum water content (50-60\%). The results showed that the biodegradation of PAH that occurs is not affected by soil $p H$ conditions. This is evidenced by the percentage of degraded PAH levels do not vary much between initial soil $\mathrm{pH}$ of acidic and neutral in the ratio of $\mathrm{T} / \mathrm{s} 25 / 75$ ie $75.15 \%$ and $76.21 \%$.
\end{abstract}

Keywords: Coal, bioremediation, co-composting, $P A H, p H$. 


\section{PENDAHULUAN}

Batubara yang merupakan endapan dari tumbuhan purba adalah salah satu sumber $\mathrm{PAH}$ secara alami. Pembentukan batubara terjadi melalui 2 tahap yaitu diagenesis (penggambutan) dan catagenesis (pembatubaraan). Pada tahap diagenesis tumbuhan purba dalam kondisi anaerobik diubah menjadi humus kemudian gambut oleh bakteri anaerobik dan fungi. Kemudian komponen organik dalam gambut dengan pengaruh suhu, tekanan, dan waktu diubah menjadi batubara muda (tahap catagensis) hingga batubara matang. Urutan batubara dari yang muda hingga matang adalah lignite, subbituminous, bituminous, anthracite, dan graphite. Menurut Achten dan Hofmaan (2009), tingkat kematangan batubara dapat ditentukan dari jumlah cincin aromatik pada tumbuhan seperti lignin. Semakin banyak lignin yang terkandung maka akan semakin matang batubara yang terbentuk. Ribeiro dkk. (2012) dan Yoshioka dan Takeda (2004) menjelaskan bahwa lebih dari 50\% kandungan batubara merupakan bahan organik yaitu asam humat dan PAH.

Batubara mengandung 16 jenis PAH yang diutamakan oleh US-EPA dengan kadar 100 kali lebih tinggi dibandingkan dengan crude oil (Laumann dkk., 2011; Achten dan Hofmaan, 2009; dan Richter dan Howard 2000). 16 jenis PAH tersebut adalah naphthalene, acenaphthylene, acenaphthene, fluorine, antracene, phenanthrene, fluoranthene, pyrene, benzo(a)antracene, chrysene, benzo(b)fluoranthene, benzo(k)fluoranthene, benzo(a)pyrene, indeno[1,2,3-cd]pyrene, benzo[g,h,i]perylene, dibenzo[a,h]anthracene (Bojes dan Pope 2007; Antizar-Ladislao dkk., 2004b). Azizi dkk. (2012); Banger dkk. (2010); Bamforth dan Singleton (2005); Antizar-Ladislao dkk. (2004a), (2004b) menjelaskan bahwa PAH adalah senyawa hidrokarbon yang memiliki dua atau lebih struktur cincin aromatik yang bersifat hidrofobik. Hidrofobik artinya memiliki tingkat kelarutan yang rendah terhadap air sehingga kontaknya dengan mikroorganisme menjadi terbatas. Hal ini mengakibatkan PAH sulit didegradasi dan berpotensi terakumulasi di dalam tanah.

Mengingat batubara adalah salah satu sumber PAH secara alami, maka lahan-lahan pada lokasi pertambangan memiliki potensi besar untuk terkontaminasi. Mizwar dan Trihadiningrum (2014), menyebutkan bahwa lokasi stockpile, hauling road, dan pelabuhan khusus batubara pada salah satu fasilitas pengangkutan batubara di Kabupaten Tapin, Provinsi Kalimantan Selatan kadar PAH yang terkandung berturut-turut adalah sebesar 11,79 $\mathrm{mg} / \mathrm{kg} ; \quad 32,33 \mathrm{mg} / \mathrm{kg} ;$ dan $55,30 \mathrm{mg} / \mathrm{kg}$. Meskipun di Indonesia belum ada aturan yang menetapkan kadar maksimal PAH dalam tanah. Namun, jika dibandingkan dengan peraturan yang berlaku di Belanda dan Amerika Serikat yang menetapkan $1 \mathrm{mg} / \mathrm{kg}$ sebagai kadar maksimal PAH dalam tanah (Antizar-Ladislao dkk., 2004a), maka perlu dilakukan upaya remediasi pada lokasi-lokasi yang terkontaminasi.

Co-composting adalah salah satu teknik bioremediasi yang terbukti mampu menurunkan kadar PAH dalam tanah tanpa biaya besar (Zhang dkk., 2011; AntizarLadislao dkk., 2004a, 2004b). Proses cocomposting tersebut dipengaruhi oleh berbagai faktor yaitu suhu, rasio $\mathrm{C} / \mathrm{N}, \mathrm{pH}$, ketersediaan oksigen, kadar air, dan viabilitas mikroorganisme (Bamforth dan Singleton, 2005). Antizar Ladislao dkk. (2004a) melaporkan bahwa co-composting dengan mencampurkan sampah organik dan tanah terkontaminasi $\mathrm{PAH}$ sebagai starter dengan rasio $0,8 / 1$, suhu $38^{\circ} \mathrm{C}$, kadar air $60 \%$ dalam waktu 98 hari dapat menurunkan kadar PAHtar batubara dari industri gas sebesar 75,2\%. Sedangkan penelitian yang dilakukan oleh Zhang dkk. (2011) yang menggunakan tanah terkontaminasi PAH dari lokasi industri batubara dengan perlakuan sama selama 60 hari dapat mereduksi kadar $\mathrm{PAH}$ rata-rata sebesar 50,5\%. Namun, kajian mengenai pengaruh $\mathrm{pH}$ tanah dalam proses bioremediasi tanah terkontainasi PAH belum banyak dilakukan. Maka dilakukan pendekatan untuk mengetahui pengaruh $\mathrm{pH}$ tanah yang rendah dalam proses biodegradasi PAH.

\section{METODE PENELITIAN}

\section{Tanah Terkontaminasi PAH-Batubara}

Tanah terkontaminasi PAH diambil dari area pelabuhan khusus batubara pada salah satu fasilitas transportasi batubara di Kabupaten Tapin, Provinsi Kalimantan Selatan. Tanah diambil dari 6 titik lokasi 
Gina Lova Sari, Andy Mizwar, Yulinah Trihadiningrum: Pengaruh PH Tanah Terhadap Proses Biodegradasi Polycyclic Aromatic Hydrocarbon (PAH) Pada Tanah Terkontaminasi Batubara

Jurnal Teknologi. 8 (1) pp 31-38 @ 2016

sampling yang kemudian dicampur dengan metode komposit dan dianalisis. Hasil analisis menyatakan bahwa tanah tersebut termasuk dalam kelas tekstur tanah lempung berpasir (sandy loam) dengan kandungan pasir 62\%, debu $19 \%$, dan liat 19\%. Rasio $\mathrm{C} / \mathrm{N}$ tanah adalah 12,59 dengan kadar air 59\% dan derajat keasaman $(\mathrm{pH})$ yang netral yaitu 7. Analisis kadar total 16 EPA-PAH dilakukan pada tanah yang telah diayak menggunakan saringan 10 mesh (2 mm) dengan hasil sebesar 59,15 $\mathrm{mg} / \mathrm{kg}$.

\section{Sampah Organik}

Sampah organik yang digunakan berasal dari Rumah Kompos Kebun Bibit dan Pasar Keputran, Surabaya. Sampah organik terdiri dari daun, ranting, dan kol yang dicampur dengan perbandingan 5:3:2 dalam berat basah. Sebelum dianalisis, ketiga jenis sampah campur dan diayak menggunakan saringan 10 mesh $(2 \mathrm{~mm})$. Hasil analisis menunjukkan rasio $\mathrm{C} / \mathrm{N}$ dari sampah organik adalah 23,92; kadar air 58\%; pH 6,5; dan kadar total 16 EPA-PAH sebesar $3,43 \mathrm{mg} / \mathrm{kg}$.

\section{Campuran Tanah Terkontaminasi PAH- Batubara dengan Sampah Organik}

Rasio campuran tanah terkontaminasi PAH dengan sampah organik (rasio T/S) terdiri dari 5 komposisi yaitu 100/0, 75/25, $50 / 50,25 / 75$, dan 0/100. Rasio C/N dari kelima rasio $\mathrm{T} / \mathrm{S}$ ini secara berurutan adalah 12,$59 ; 13,32 ; 16,31 ; 18,64 ;$ dan 23,92. Sedangkan kadar total 16 EPA-PAH masingmasing secara berurutan adalah $59,15 \mathrm{mg} / \mathrm{kg}$, $59,65 \mathrm{mg} / \mathrm{kg}, 60,50 \mathrm{mg} / \mathrm{kg}, 60,73 \mathrm{mg} / \mathrm{kg}$, dan $3,43 \mathrm{mg} / \mathrm{kg}$ berat basah. Kadar total PAH lebih tinggi pada campuran tanah terkontaminasi dengan sampah organik karena $\mathrm{PAH}$ juga terdeteksi pada sampah organik.

\section{Desain Penelitian}

Penelitian ini merupakan penelitian eksperimental dengan skala laboratorium menggunakan 10 reaktor dengan kapasitas $3500 \mathrm{ml}$ selama 98 hari. Bahan baku yang digunakan dalam penelitian ini adalah campuran tanah terkontaminasi PAH dengan sampah organik sebanyak $1 \mathrm{~kg}$ berat basah dengan 2 variasi yang meliputi rasio T/S dan $\mathrm{pH}$ tanah. Rasio T/S divariasikan menjadi 5 yaitu 100/0, 75/25, 50/50, 25/75, dan 0/100. Sedangkan $\mathrm{pH}$ tanah dikondisikan asam yaitu 5 dengan penambahan $\mathrm{H}_{2} \mathrm{SO}_{4}$ dan netral yaitu
7 yang merupakan $\mathrm{pH}$ eksisting dari sampel tanah. Proses co-composting dalam penelitian ini dilakukan secara aerobik dengan kapasitas moisture aeration yang diberikan $0,5 \mathrm{~L} /$ menit. Moisture aeration dilakukan untuk memenuhi kebutuhan oksigen mikroorganisme dan menjaga kadar air berada dalam rentang optimum yaitu $50-60 \%$.

\section{Analisis Kadar PAH}

Ekstraksi sampel penelitian dilakukan dengan metode ultrasonic dengan beberapa modifikasi (Schwarzbauer dkk., 2000). Ekstraksi dilakukan dengan 2 kali pengulangan menggunakan pelarut (solvent) yang berbeda. $5 \mathrm{~g}$ sampel penelitian ditambahkan $30 \mathrm{ml}$ dichloromethane (DCM) kemudian diekstraksi menggunakan ultrasonic cleaner SIBATA SU-3THE selama 10 menit. Sampel dipisahkan dengan hasil ekstraksi menggunakan saringan yang telah ditambahkan $\mathrm{Na}_{2} \mathrm{SO}_{4}$ kemudian dipekatkan hingga $1 \mathrm{ml}$ menggunakan rotary evaporator. Langkah ekstraksi dilakukan kembali pada sampel yang telah dipisahkan menggunakan $n$ pentane sebanyak $30 \mathrm{ml}$. Kedua hasil ekstraksi di campur dan ditambahkan sedikit cooper sulfat untuk menghilangkan sulfur. Kolom kromatografi disiapkan untuk proses fraksinasi dengan memasukkan glass wool dan bubuk silika MERCK 7754 sebanyak 2 g. Sebelum itu, kolom kromatografi dibersihkan menggunakan DCM. Pada kolom kromatografi silika yang telah siap dialirkan $10 \mathrm{ml}$ DCM sehingga membentuk matriks silika yang kompak. Sebanyak $1 \mathrm{ml}$ hasil ekstraksi diambil dan dialirkan ke dalam kolom silika. Ditambahkan DCM/n-pentane (60/40) hingga didapatkan $7 \mathrm{ml}$ fraksi 2 (F2). Senyawa PAH diukur dengan menganalisis F2 menggunakan GC-MS Thermo Scientific Trace 1310 ISQ single quadrupole dengan metode MacLeod dkk. (1993) dan Grasshoff dkk. (1983).

\section{HASIL DAN PEMBAHASAN}

Proses co-composting tanah terkontaminasi dengan sampah organik ini bertujuan untuk mengetahui pengaruh $\mathrm{pH}$ tanah dalam proses biodegradasi PAH. Selama 98 hari proses co-composting berlangsung dalam kondisi optimum. Kondisi tersebut ditandai dengan tersedianya oksigen dan kadar air optimum (50-60\%) yang tercipta dari awal hingga akhir proses co-composting. 
Ketersediaan oksigen dan kadar air dijaga melalui moisture aeration dengan kapasitas 0,5 L/menit. Pada kondisi tersebut mikroorganisme dapat beraktivitas dengan baik (lihat Tabel 1).

Aktivitas mikroorganisme tersebut ditunjukkan dengan tercapainya suhu mesofilik yang berkisar antara $30-33^{\circ} \mathrm{C}$. Suhu tersebut mengalami peningkatan $1-2^{\circ} \mathrm{C}$ yang menandakan bahwa terbentuk energi berupa panas dari proses dekomposisi bahan organik. Selain energi, proses dekomposisi juga menghasilkan $\mathrm{CO}_{2}$, air, dan biomassa. Proses dekomposisi dapat berlangsung karena nutrien yang dibutuhkan oleh mikroorganisme tercukupi. Hal ini ditandai dengan rasio $\mathrm{C} / \mathrm{N}$ awal yang berkisar antara 12,59-23,92. Nilai tersebut sebagian besar memenuhi rasio $\mathrm{C} / \mathrm{N}$ yang disyaratkan oleh Antizar-Ladislao (2007) yaitu 15-30.

Faktor lain yang mempengaruhi aktivitas mikroorganisme dalam proses co- composting adalah $\mathrm{pH}$. Mikroorganisme mampu bertahan hidup dan berkembang biak pada $\mathrm{pH}$ tertentu sesuai denga karakteristiknya masing-masing Umumnya, mikroorganisme tidak mampu bertahan hidup pada kondisi $\mathrm{pH}$ yng terlalu rendah dan terlalu tinggi (Sayara dkk., 2009; Tchobanoglous dkk., 1993). Nilai $\mathrm{pH}$ tanah dalam penelitian ini dikondisikan menjadi asam yaitu 5 dan netral yaitu 7 yang merupakan kondisi eksisting sampel tanah yang digunakan.

Setelah dilakukan pencampuran sampel tanah dengan sampah organik, nilai $\mathrm{pH}$ menjadi bervariasi. Pada tanah asam, nilai $\mathrm{pH}$ bervariasi menjadi 5-5,3 sedangkan tanah dengan kondisi netral $\mathrm{pH}$ sedikit mengalami penurunan menjadi 6-7. Penurunan terjadi karena $\mathrm{pH}$ sampah organik yang rendah, khususnya kol adalah 5 sehingga mempengaruhi $\mathrm{pH}$ campuran. Perubahan $\mathrm{pH}$ yang terjadi selama proses co-composting dapat dilihat pada Gambar 1.

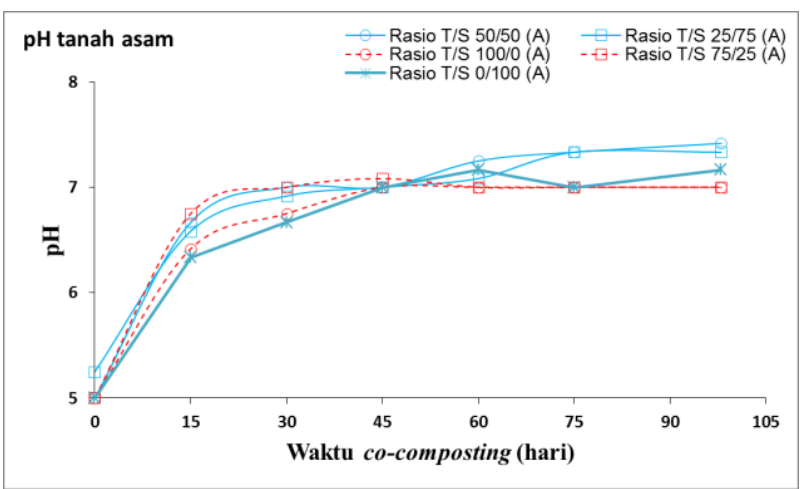

(a) Variasi pH Tanah Asam

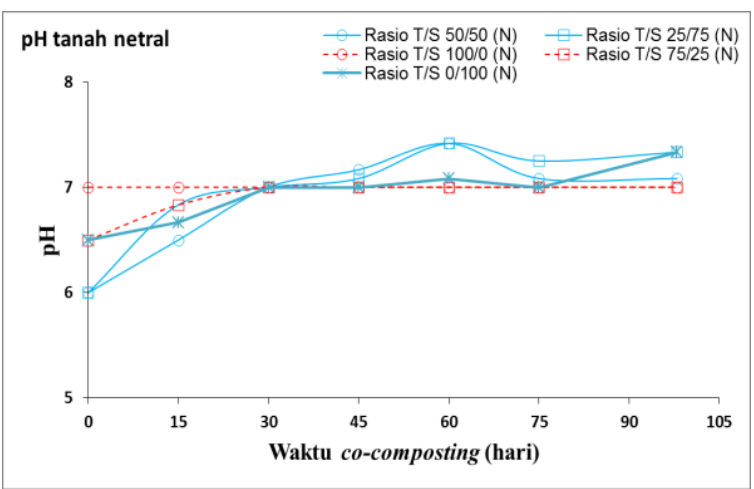

(b) Variasi pH Tanah Netral

Gambar 1. Perubahan pH Tanah Selama Proses Co-Composting

Gambar 1 menunjukkan sampel tanah dengan variasi asam pada $\mathrm{H}-15$ meningkat tajam menjadi 6,3-6,8. Nilai $\mathrm{pH}$ terus meningkat menuju kisaran netral yaitu 7-7,5 pada $\mathrm{H}-30$ hingga $\mathrm{H}-98$. Peningkatan yang serupa juga terjadi pada sampel tanah dengan variasi $\mathrm{pH}$ netral. Pada sampel campuran, $\mathrm{pH}$ awal berkisar antara 6-6,5 meningkat menjadi 6,5-7,0 di $\mathrm{H}-15$ yang kemudian terus bergerak pada kisaran netral hingga H-98. Peningkatan pH pada kisaran netral juga dialami oleh Karnchanawong dan Sapudom (2011), Atagana (2008), dan Boonchan (2000) dalam proses co-composting yang dilakukan oleh ketiganya dalam 4-5 bulan pertama.

Peningkatan $\mathrm{pH}$ yang terjadi disebabkan oleh terbentuknya senyawa bikarbonat $\left(\mathrm{H}_{2} \mathrm{CO}_{3}\right)$ dari reaksi $\mathrm{CO}_{2}$ dan air hasil dekomposisi bahan organik. Unsur-unsur penyusun $\mathrm{H}_{2} \mathrm{CO}_{3}$ adalah $\mathrm{HCO}_{3}^{-}$dan $\mathrm{H}^{+}$yang merupakan senyawa buffer yaitu senyawa yang memiliki daya sangga $\mathrm{pH}$. Pada kondisi keasaman yang tinggi, akan dilepaskan $\mathrm{OH}^{-}$ untuk menetralkannya, begitu pula sebaliknya (Padmono, 2007). Dari prosesnya tersebut, maka dapat dilihat bahwa reaksi dari kedua senyawa tersebut merupakan reaksi 
Gina Lova Sari, Andy Mizwar, Yulinah Trihadiningrum: Pengaruh PH Tanah Terhadap Proses Biodegradasi Polycyclic Aromatic Hydrocarbon (PAH) Pada Tanah Terkontaminasi Batubara

Jurnal Teknologi. 8 (1) pp 31-38 @ 2016

kesetimbangan yang akan melengkapi satu sama lain. Nilai $\mathrm{pH}$ yang bertahan pada kisaran netral hingga H-98 juga merupakan pengaruh dari buffer.

Proses nitrifikasi yang terjadi selama proses co-composting juga menjadi salah satu faktor yang mempengaruhi peningkatan $\mathrm{pH}$. Nitrifikasi adalah proses oksidasi ammonia $\left(\mathrm{NH}_{3}\right)$ yang merupakan N-organik tanah menjadi nitrit $\left(\mathrm{NO}_{2}{ }^{-}\right)$. Kemudian $\mathrm{NO}_{2}{ }^{-}$dirubah menjadi nitrat $\left(\mathrm{NO}_{3}^{-}\right)$. Bersamaan dengan proses tersebut, ion $\mathrm{H}^{+}$terlepas sehingga kandungannya dalam tanah berkurang dan digantikan oleh kation-kation basa (pertukaran ion). Hal ini mengakibatkan kadar kemasaman tanah menurun, artinya $\mathrm{pH}$ tanah menjadi netral atau basa (Atagana, 2008). Pertukaran ion ini lazimnya disebut kapasitas tukar kation (KTK). KTK dipengaruhi oleh ketersediaan kation-kation basa pada bahan baku composting. Bell dan Besho (1993) dalam Yuwono (2008) menjelaskan bahwa penambahan sampah organik ke dalam tanah dapat meningkatkan ketersediaan kationkation basa seperti $\mathrm{Ca}^{2+}, \mathrm{Mg}^{2+}, \mathrm{K}^{+}$, dan $\mathrm{Na}^{+}$ pada tanah masam.
Peningkatan $\mathrm{pH}$ lebih tajam terlihat pada variasi tanah dengan $\mathrm{pH}$ asam dibandingkan netral. Hal ini sesuai dengan penjelaskan Mrozik dkk. (2003) yaitu pada pH rendah ketersediaan unsur hara lebih tinggi sehingga aktivitas mikroorganisme juga akan meningkat. Peningkatan aktvitas mikroorganisme ini didukung oleh jumlah bakteri pada variasi tanah $\mathrm{pH}$ asam sebagian besar lebih banyak dibandingkan dengan variasi tanah $\mathrm{pH}$ netral. Data pertumbuhan bakteri secara lengkap disajikan pada Tabel 1. Semakin banyak jumlah mikroorganisme makan semakin tinggi pula metabolismenya sehingga pembentukan $\mathrm{H}_{2} \mathrm{CO}_{3}$ semakin cepat. Nilai $\mathrm{pH}$ pada kedua variasi $\mathrm{pH}$ tanah pada $\mathrm{H}-$ 30 hingga $\mathrm{H}-98$ berkisar pada nilai yang hampir sama yaitu 7-7,3 (asam) dan 7-7,4 (netral). Rynk (1992) menyatakan bahwa kisaran $\mathrm{pH}$ tersebut merupakan kondisi optimal untuk pertumbuhan mikroorganisme yang didukung dengan peningkatan jumlah bakteri hingga $\mathrm{H}-98$. Kondisi $\mathrm{pH}$ netral pada proses co-composting yang berlangsung menyebabkan pertumbuhan bakteri tidak mengalami perbedaan yang besar diantara kedua jenis variasi $\mathrm{pH}$ tanah.

Tabel 1. Pertumbuhan Bakteri Selama Proses Co-Composting

\begin{tabular}{|c|c|c|c|c|c|c|c|c|}
\hline \multirow{2}{*}{$\begin{array}{c}\text { Rasio } \\
\mathbf{T} / \mathbf{S}\end{array}$} & \multirow{2}{*}{ Variasi } & \multicolumn{7}{|c|}{ Hari ke- } \\
\hline & & 0 & 15 & 30 & 45 & 60 & 75 & 98 \\
\hline \multirow{2}{*}{$100 / 0$} & Asam & $3,36 \times 10^{7}$ & $\begin{array}{c}1,73 \mathrm{x} \\
10^{11}\end{array}$ & $\begin{array}{c}8,91 \mathrm{x} \\
10^{11}\end{array}$ & $\begin{array}{c}2,33 \mathrm{x} \\
10^{12}\end{array}$ & $\begin{array}{c}2,15 \times \\
10^{13}\end{array}$ & $\begin{array}{c}8,51 \mathrm{x} \\
10^{15}\end{array}$ & $\begin{array}{c}5,46 \times \\
10^{19}\end{array}$ \\
\hline & Netral & $7,53 \times 10^{7}$ & $\begin{array}{c}6,50 \mathrm{x} \\
10^{10}\end{array}$ & $\begin{array}{c}5,05 \mathrm{x} \\
10^{10}\end{array}$ & $\begin{array}{c}1,76 \times \\
10^{12}\end{array}$ & $\begin{array}{c}3,36 \mathrm{x} \\
10^{13}\end{array}$ & $\begin{array}{c}4,70 x \\
10^{19}\end{array}$ & $\begin{array}{c}2,33 \times \\
10^{20}\end{array}$ \\
\hline \multirow{2}{*}{$75 / 25$} & Asam & $4,63 \times 10^{8}$ & $\begin{array}{c}1,11 \mathrm{x} \\
10^{12} \\
\end{array}$ & $\begin{array}{c}1,23 \mathrm{x} \\
10^{12}\end{array}$ & $\begin{array}{c}3,45 \times \\
10^{13} \\
\end{array}$ & $\begin{array}{c}2,88 \times \\
10^{18} \\
\end{array}$ & $\begin{array}{c}2,18 \mathrm{x} \\
10^{20} \\
\end{array}$ & $\begin{array}{c}1,05 \mathrm{x} \\
10^{21}\end{array}$ \\
\hline & Netral & $\begin{array}{c}2,86 \times \\
10^{11} \\
\end{array}$ & $\begin{array}{c}3,79 \mathrm{x} \\
10^{13}\end{array}$ & $\begin{array}{c}1,25 \mathrm{x} \\
10^{13}\end{array}$ & $\begin{array}{c}2,41 \mathrm{x} \\
10^{15}\end{array}$ & $\begin{array}{c}3,46 \times \\
10^{16}\end{array}$ & $\begin{array}{c}5,29 \mathrm{x} \\
10^{17}\end{array}$ & $\begin{array}{c}3,17 \times \\
10^{20}\end{array}$ \\
\hline \multirow{2}{*}{$50 / 50$} & Asam & $3,86 \times 10^{8}$ & $\begin{array}{c}6,31 \mathrm{x} \\
10^{11}\end{array}$ & $\begin{array}{c}1,60 \mathrm{x} \\
10^{13}\end{array}$ & $\begin{array}{c}7,16 \times \\
10^{14}\end{array}$ & $\begin{array}{c}3,64 \times \\
10^{18}\end{array}$ & $\begin{array}{c}2,71 \times \\
10^{20}\end{array}$ & $\begin{array}{c}1,79 \mathrm{x} \\
10^{19}\end{array}$ \\
\hline & Netral & $\begin{array}{c}7,59 x \\
10^{12}\end{array}$ & $\begin{array}{c}3,71 \mathrm{x} \\
10^{11}\end{array}$ & $\begin{array}{c}2,68 \mathrm{x} \\
10^{11}\end{array}$ & $\begin{array}{c}1,26 \mathrm{x} \\
10^{14}\end{array}$ & $\begin{array}{c}1,69 \mathrm{x} \\
10^{20}\end{array}$ & $\begin{array}{c}1,64 \mathrm{x} \\
10^{18}\end{array}$ & $\begin{array}{c}2,69 \times \\
10^{21}\end{array}$ \\
\hline \multirow{2}{*}{$25 / 75$} & Asam & $4,78 \times 10^{8}$ & $\begin{array}{c}1,46 \times \\
10^{12}\end{array}$ & $\begin{array}{c}1,75 \mathrm{x} \\
10^{12}\end{array}$ & $\begin{array}{c}5,26 \times x \\
10^{13} \\
\end{array}$ & $\begin{array}{c}2,27 \times \\
10^{14}\end{array}$ & $\begin{array}{c}2,30 \mathrm{x} \\
10^{19}\end{array}$ & $\begin{array}{c}2,95 \mathrm{x} \\
10^{21}\end{array}$ \\
\hline & Netral & $\begin{array}{c}8,68 \mathrm{x} \\
10^{11} \\
\end{array}$ & $\begin{array}{c}2,85 \mathrm{x} \\
10^{11}\end{array}$ & $\begin{array}{c}4,64 \times \\
10^{11}\end{array}$ & $\begin{array}{c}3,87 \mathrm{x} \\
10^{13}\end{array}$ & $\begin{array}{c}6,80 \times \\
10^{14}\end{array}$ & $\begin{array}{c}3,70 \mathrm{x} \\
10^{18}\end{array}$ & $\begin{array}{c}1,53 \times \\
10^{20}\end{array}$ \\
\hline \multirow{2}{*}{$0 / 100$} & Asam & $2,54 \times 10^{8}$ & $\begin{array}{c}3,27 \mathrm{x} \\
10^{11}\end{array}$ & $\begin{array}{c}3,46 \mathrm{x} \\
10^{13}\end{array}$ & $\begin{array}{c}3,93 \times \\
10^{13}\end{array}$ & $\begin{array}{c}3,14 \mathrm{x} \\
10^{14}\end{array}$ & $\begin{array}{c}2,23 \mathrm{x} \\
10^{16}\end{array}$ & $\begin{array}{c}1,79 \mathrm{x} \\
10^{22}\end{array}$ \\
\hline & Netral & $\begin{array}{c}, 46 \mathrm{x} \\
10^{11}\end{array}$ & $\begin{array}{c}3,85 \mathrm{x} \\
10^{11}\end{array}$ & $\begin{array}{c}2,71 \mathrm{x} \\
10^{11}\end{array}$ & $\begin{array}{c}1,32 \times \\
10^{14}\end{array}$ & $\begin{array}{c}1,23 \mathrm{x} \\
10^{17}\end{array}$ & $\begin{array}{c}7,17 \times \\
10^{22}\end{array}$ & $\begin{array}{c}2,44 \times x \\
10^{19}\end{array}$ \\
\hline
\end{tabular}


Pertumbuhan bakteri yang perbedaannya tidak besar tentu saja mempengaruhi efisiensi degradasi yang terjadi. Kadar awal dan akhir PAH selama proses co-composting dapat dilihat pada Gambar 2. Kadar awal PAH pada rasio T/S 100/0; 75/25; 50/50; dan 25/75 berkisar antara 58,41-61,69 mg/kg. Kadar PAH ini lebih tinggi dibandingkan dengan nilai PAH awal yaitu $59,15 \mathrm{mg} / \mathrm{kg}$ karena sampah organik yang ditambahkan juga mengandung PAH. Pernyataan ini didukung dengan hasil analisis $\mathrm{PAH}$ pada rasio T/S 0/100 yang menunjukkan nilai 3,06-3,78 mg/kg. Hal ini disebabkan oleh sampah organik mengandung lignin yang merupakan salah satu penyusun PAH.

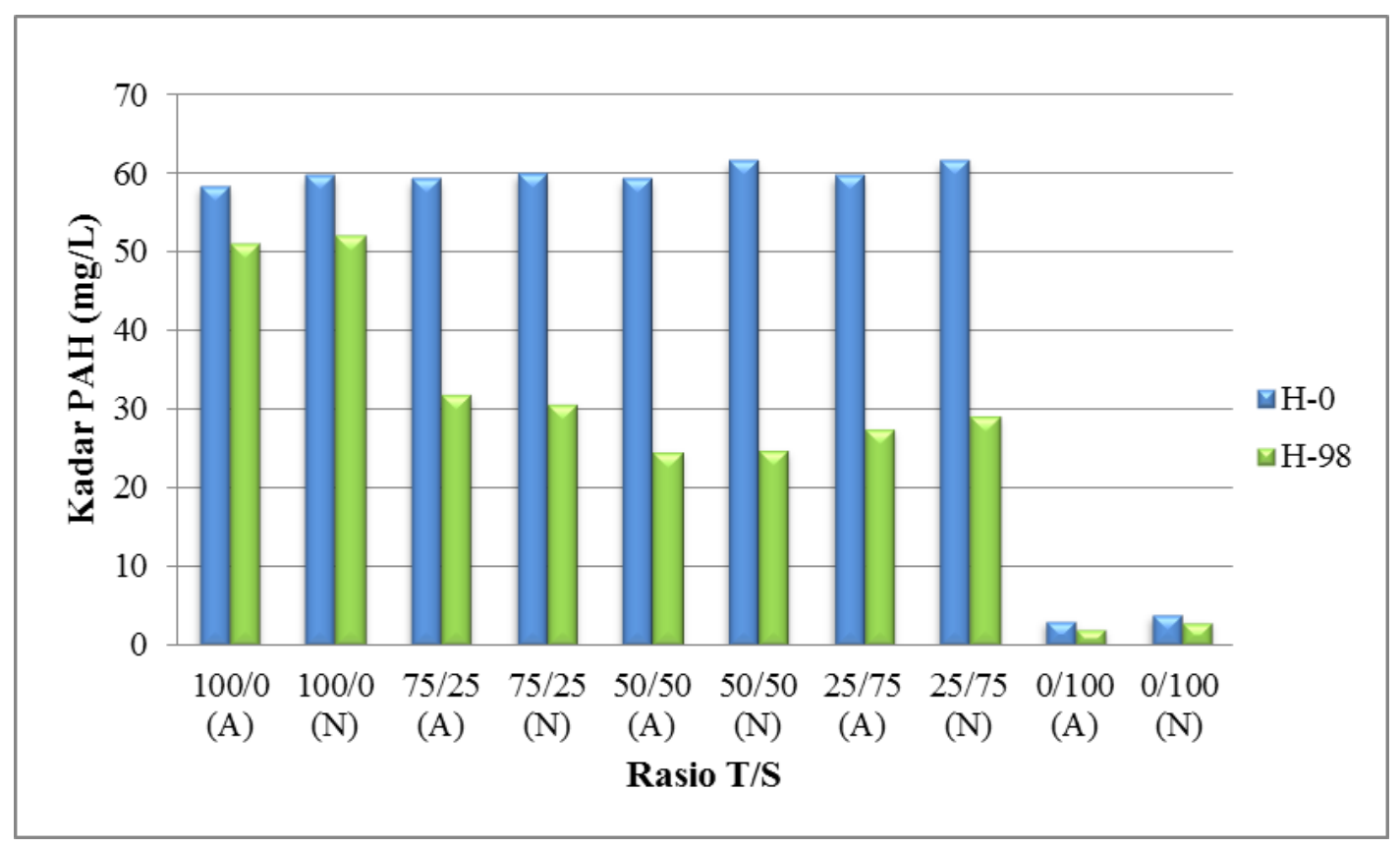

Gambar 2. Kadar PAH Selama Proses Co-Composting

Selama proses co-composting, terjadi penurunan kadar $\mathrm{PAH}$ yang cukup tinggi. Penurunan terbesar terlihat pada rasio T/S 50/50 dalam kondisi netral yang menunjukkan efisiensi sebesar 59,89\%. Hal ini membuktikan bahwa penambahan sampah organik dalam proses co-composting mampu menjadi stimulan bagi mikroorganisme sehingga degradasi PAH lebih besar. Namun, jika dibandingkan dengan rasio T/S 25/75 dengan $\mathrm{pH}$ tanah asam efisiensinya mencapai $58,49 \%$. Dapat dilihat bahwa perbedaan sangat kecil yaitu $1,4 \%$. Hal ini menunjukkan bahwa $\mathrm{pH}$ tanah yang asam tidak memiliki pengaruh terhadap proses biodegradasi karena proses $\mathrm{co}$ composting sebagian besar berjalan dalam kondisi $\mathrm{pH}$ netral.

\section{KESIMPULAN}

Penambahan sampah organik dalam proses co-composting mampu meningkatkan aktivitas mikroorganisme sehingga tingkat degradasinya lebih besar. Degradasi PAH paling besar ditemukan pada rasio T/S 50/50 dalam variasi $\mathrm{pH}$ tanah netral yaitu 59,89\%. Tingkat degradasinya hanya memiliki sedikit perbedaan dengan variasi $\mathrm{pH}$ tanah asam yaitu $58,49 \%$. Hal ini menunjukkan bahwa kondisi $\mathrm{pH}$ tanah tidak memiliki pengaruh yang besar terhadap proses biodegradasi PAH dalam proses co-composting.

\section{DAFTAR PUSTAKA}

Achten, C., dan Hofmann, T. (2009). Native Polycyclic Aromatic Hydrocarbons (PAH) in Coals - A Hardly Recognized Source of Environmental Contamination. Science of The Total Environment, Vol. 407 (8): 2461-2473. Antizar-Ladislao, B., Lopez-Real, J., Beck, A. J. (2004a). In-Vessel CompostingBioremediation of Aged Coal Tar Soil: Effect of Temperature and Soil/Green 
Gina Lova Sari, Andy Mizwar, Yulinah Trihadiningrum: Pengaruh PH Tanah Terhadap Proses Biodegradasi Polycyclic Aromatic Hydrocarbon (PAH) Pada Tanah Terkontaminasi Batubara

Jurnal Teknologi. 8 (1) pp 31-38 @ 2016

Waste Amendment Ratio. Environment International, 31: 173-178.

Antizar-Ladislao, B., Lopez-Real, J., Beck, A. J. (2004b). Bioremediation of Polycyclic Aromatic Hydrocarbon (PAH) Contaminated Waste Using Composting Approaches. Environmental Science and Technology, 34: 249-289.

Antizar-Ladislao, B., dan Russell, N. J. (2007). In-Vessel Composting as a Sustainable Bioremediation Technology of Contaminated Soils and Waste. Nova Science Publishers, Inc.

Atagana, H. I. (2008). Compost Bioremediation of HydrocarbonContaminated Soil Inoculated with Organic Manure. African Journal of Biotechnology, Vol. 7: 1516-1525.

Azizi, A. B., Liew, K. Y., Noor, Z. M., Abdullah, N. (2013). Vermiremediation and Mycoremediation of Polycyclic Aromatic Hydrocarbons in Soil and Sewage Sludge Mixture: A Comparative Study. International Journal of Environmental Science and Development, Vol. 4 No. 5.

Bamforth, S. M., dan Singleton, I. (2005). Bioremediation of Polycyclic Aromatic Hydrocarbons: Current Knowledge and Future Directions. Journal of Chemical Technology and Biotechnology, 80: 723-736.

Banger, K., Toor, G. S., Chirenje, T., Ma, L. (2010). Polycyclic Aromatic Hydrocarbons in Urban Soils of Different Land Uses in Miami, Florida. Soil and Sediment Contamination, 19: 231-243.

Bojes, H. K., dan Pope, P. G. (2007). Characterization of EPA's 16 Priority Polycyclic Aromatic Hydrocarbons (PAH) in Tank Bottom Solids and Associated Contaminated Soils at Oil Exploration and Production Sites in Texas. Reg. Toxicology and Pharmacology. 47: 288-295.

Boonchan, S., Britz, M. L., Stanley, G. A. (2000). Degradation and Mineralization of High-Molecular-Weight Polycyclic Aromatic Hydrocarbons by Defined Fungal-Bacterial Cocultures. Applied and Environmental Microbiology, p. 1007-1019.
Karnchanawong, S., dan Sapudom, K. (2011). Effect of Ratio and Moisture Contens on Performance of Haoushold Organic Waste Composting Using Passive Aeration Bin. Second International Conference on Chemical Engineering and Applications, Vol 23.

Laumann, S., Micic, V., Kruge, M. A., Achten, C., Sachsenhofer, R. F., Schwarzbauer, J., Hofmann, T. (2011).Variations in Concentrations and Compositions of Polycyclic Aromatic Hydrocarbons (PAH) in Coals Related to the Coal Rank and Origin.Environmental pollution, 159(10): 2690-2697.

MacLeod, W. D. Jr., Brown, D. W., Friedman, A. J., Burrows, D. G., Maynes, O., Pearch, R. W., Wigren, C. A., Bogar, R. G. (1993). Standard Analytical Procedures of the NOAA National Analytical Facility. 1985-1986.

Mizwar, A., dan Trihadiningrum, Y. (2014). Potensi Bioremediasi Tanah Terkontaminasi Polycyclic Aromatic Hydrocarbons dari Batubara dengan Composting. Seminar Nasional Waste Management II. ISBN: 976-002-955957-6.

Mrozik, A., Piotrowska-Seget, Z., Labuzek, S. (2003). Bacterial Degradation and Bioremediation of Polycyclic Aromatic Hydrocarbons. Polish Journal of Environmental Studies, Vol. 12, No. 1; 15-25.

Padmono, D. (2007). Kemampuan Alkalinitas Kapasitas Penyanggaan (Buffer Capacity) dalam Sistem Anaerobik Fixed Bed. Jurnal Teknologi Lingkungan, Vol. 8, No. 2: 119-127.

Ribeiro, J., Silva, T., Mendonca-Filho, J. G., Flores, D. (2012). Polycyclic Aromatic Hydrocarbons (PAH) in Burning and Non-Burning Coal Waste Piles. Journal of Hazardous Material, Vol. 199-200; 105-110.

Richter, H., dan Howard, J. B. (2000). Formation of Polycyclic Aromatic Hydrocarbons and Their Growth to Soot-A Review of Chemical Reaction Pathways. Progress in Energy and Combustion Science, Vol. 26 (4-6); 565-608. 
Rynk, R. (1992). On-Farm Composting Handbook. North-east Regional Agricultural Engineering Service Pub. No. 54. Cooperative Extension Service. Ithaca, New York.

Sayara, T., Sarra, M., Sanchez, A. (2009). Effect of Composting Controlling Factors on the Bioremediation of Polycyclic Aromatic Hydrocarbons (PAH) Contaminated Soil. Palstine: Proceedings of the Second International Conference on Energy and Environmental Protection in the Sustainable Development.

Schwarzbauer, J., Littke, R., Weigelt, V. (2000). Identification of Specific Organic Contaminants for Estimating the Contribution of the Elbe River to the Pollution of the German Bight. Organic Geochemistry, 31: 1713-1731.
Tchobanoglous, G., Theisen, H., Vigil, S. A. (1993). Integrated Solid Waste Management. Engineering Principles and Management Issue, McGraw Hill International Editions.

Yoshioka, H., dan Takeda, N. (2004). Analysis of Organic Compounds in Coal Materials by Infrared Laser Micropyrolysis. Journal of Analytical and Applied Pyrolysis, 71(1), 137-149.

Yuwono, D. (2008). Kompos. Bandung: Penerbit Penebar Swadaya.

Zhang, Y., Zhu, Y., Houot, S., Qiao, M., Nunan, N., Garnier, P. (2011). Remediation of Polycyclic Aromatic Hydrocarbon (PAH) Contaminated Soil Through Composting with Fresh Organik Wastes. Environmental Science Pollutan Research, 18: 1574-1584. 